\title{
Do most livestock losses to poisonous plants result from "poor" range management?
}

\author{
JERRY L. HOLECHEK
}

The author is Professor, Dept. of Animal and Range Sciences, New Mexico State Univ., Las Cruces, N.M. 88003.

Abstract

In recent years livestock death losses from poisonous plants in the western United States have averaged about 2-3\% annually. A review of 36 grazing studies in North America shows poisonous plant availability and death losses of livestock from poisonous plants are closely associated with grazing intensity. Across studies, livestock death losses to poisonous plants average about $\mathbf{2 . 0 \%}$ under moderate grazing compared with $4.8 \%$ under heavy grazing intensities. Sheep and goat losses from poisonous plants appear to be increased more by heavy stocking than those from cattle. Impacts of poisonous plants on livestock reproductive success are difficult to quantify, but probably reduce calf and lamb crops, even when grazing intensities are conservative. Increased poisonous plant consumption may explain in part why calf and lamb crops average about $7 \%$ lower under heavy compared to moderate grazing. With the exception of 1 Texas study, rotation and continuous/season long grazing systems show little differences in livestock death losses under comparable stocking rates. Certain plants, such as locoweeds (Astragalus sp.) and larkspur (Delphinium sp.), can elevate livestock death losses, even when grazing intensities are moderate or conservative. Special management programs that involve careful timing of grazing, aversive conditioning, and creation of locoweed (or larkspur)-free pastures can reduce problems with these plants. Use of adapted livestock is a critical part of minimizing poisonous plant problems. However, on some rangelands, such as those with infestations of locoweed and larkspurs, naive livestock may be less affected by poisonous plants than familiar livestock. Knowledge of poisonous plant identification, conditions of toxicity, and affects on the animal, in conjunction with conservative grazing, will in most cases avoid excessive death and productivity losses from poisonous plants. In some cases livestock can be conditioned or trained to not consume poisonous plants. It can be concluded that most livestock losses from poisonous plants are caused by poor management.

Key Words: Cattle, sheep, goats, grazing, poisonous plants, economics

This paper was supported by the New Mexico Agr. Exp. Sta., Las Cruces, NM 88003 and was part of project 1-5-27474.

Manuscript accepted 16 Aug. 01.
Resumen

En años recientes, en el oeste de Estados Unidos las perdidas por muerte de ganado debido a plantas tóxicas ocurridas promedian anualmente del $2-3 \%$. Una revisión de 36 estudios de apacentamiento realizados en Norte América muestran que la disponibilidad de plantas tóxicas y las perdidas por muerte de ganado a causa de este tipo de plantas están estrechamente asociadas con la intensidad de apacentamiento. Los estudios revisados muestran que bajo apacentamiento moderado las perdidas por muerte de ganado debido a plantas tóxicas promedian aproximadamente $2.0 \%$, comparado con $4.8 \%$ bajo intensidades de apacentamiento fuerte. $\mathrm{El}$ apacentamiento fuerte parece incrementar mas las perdidas por plantas tóxicas de caprinos y ovinos que de bovinos. Los impactos de las plantas tóxicas en el éxito reproductivo del ganado es difícil de cuantificar, pero probablemente reducen la cosecha de becerros y corderos, aun bajo intensidades de apacentamiento conservadoras. El aumento en el consumo de plantas tóxicas puede explicar en parte porque la cosecha de becerros y corderos es aproximadamente $7 \%$ menos bajo el apacentamiento fuerte que bajo el apacentamiento moderado. Con excepción de 1 estudio en Texas, los sistemas de apacentamiento rotacionales y continuo/estación larga, con cargas animal comparables, presentaron pocas diferencias en las perdidas por muerte de ganado por plantas tóxicas Ciertas plantas como "Locoweeds" (Astragalus sp.) y "Larkspur" (Delphinium sp.) pueden aumentar las perdidas por muerte de ganado, aun en intensidades de apacentamiento que son moderadas o conservadoras. Programas especiales de manejo que involucran el apacentar en el tiempo correcto, el acondicionamiento aversivo y la creación de potreros libres de "Locoweed" o "Larkspur" pueden reducir los problemas con estas plantas. El uso de ganado adaptado es una parte critica para minimizar los problemas de plantas tóxicas. Sin embargo, en algunos pastizales, tales como aquellos con infestaciones de "Locoweed" y "Larkspur", el ganado no familiarizado puede ser menos afectado por las plantas toxicas que el familiarizado. El conocimiento en la identificación de las plantas tóxicas, condiciones de toxicidad y los efectos en el animal en conjunto con un apacentamiento conservador, evitara, en muchos casos, perdidas excesivas de productividad y muertes por plantas tóxicas. En algunos casos el ganado puede ser acondicionado o entrenado para no consumir plantas tóxicas. Se puede concluir que la mayoría de las perdidas de ganado por plantas tóxicas son causadas por un manejo pobre. 
Poisonous plants have been an important problem for livestock producers using rangelands in the United States since the first pioneers from Europe began settlement of the country in the 1600's (James et al. 1992). Through the early history of range management, beginning in the late 1800 's to the present, grazing practices have been closely linked with the magnitude of livestock losses from poisonous plants (Smith 1899, Stoddert and Smith 1943, Holechek et al. 2001). Presently poisonous plants are considered to be important impediments to profitable ranching on roughly 400 million hectares of rangeland in the United States (James et al. 1992).

The issue of whether or not economically significant livestock losses from poisonous plants are a result of "poor" range management practices has long been a point of controversy among ranchers and range scientists. Some 30 long term grazing studies reviewed by Vallentine (1990), Heady and Child (1994), and Holechek et al. (2001) provide insight into this issue. More recently, several studies have evaluated how timing and intensity of livestock grazing can be manipulated to minimize losses from poisonous plants such as larkspurs and locoweeds.

In this review consideration will be given to what the various long term studies on grazing intensities and grazing systems have shown regarding poisonous plant losses. Personal observations regarding livestock losses from poisonous plants on Oregon and New Mexico rangelands will be incorporated into the discussion. Consideration will also be given to special grazing approaches to deal with poisonous plants such as locoweeds and larkspurs that may be readily consumed by livestock even when non-poisonous forage species are available. Finally, the practicality of conditioning livestock to avoid poisonous plants will be examined.

\section{Magnitude of Poison Plant Losses}

Economic losses due to livestock poisoning can be divided into 2 parts: (1) direct losses and (2) indirect losses (James 1978). Direct losses of livestock involve the effects of poison plants on livestock productivity and health. Indirect losses include those activities or costs that are incurred by a livestock operation to prevent losses or costs from poisonous plants (James et al. 1992).

It has always been difficult to quantify actual dollar losses to livestock operations from poisonous plants. This is because separation of disease, accident, and predator losses from poisonous plant losses can be difficult. Low reproductive performance and weight gains can be caused by disease and inadequate nutrition as well as poisonous plants. Some adverse effects of poisonous plants such as birth defects occur long after poisonous plant ingestion. Nevertheless, various attempts have been made to quantify economic impacts of poisonous plants on the range livestock industry.

Based on a $1 \%$ death loss in cattle, a $3.5 \%$ death loss in sheep, and a $1 \%$ decrease in calf and lamb crops due to poisonous plants, Nielsen and James (1991) estimated total annual economic losses at $\$ 340,000,000$ in the 17 western states. They used 1989 livestock numbers and prices. Based on 1999 livestock prices and livestock numbers, the estimate would be $\$ 503,000,000$. In New Mexico annual experiment station reports based on rancher interviews have shown cattle death losses to average 3-4\% and sheep death losses to average $4-6 \%$ for the 1987 to 1996 period (Torell et al. 1998). At least half of these losses are believed to be caused by poisonous plants. Gay and Dwyer (1967) suggested that over the entire western range, death losses were 2 to $3 \%$. The USDA (1968) estimated countable death losses in the western United States were 3$5 \%$. It is believed that losses in reproduction and weight gains from animals poisoned that do not die exceed those from death loss (Gay and Dwyer 1967).

Regardless of how estimates of livestock losses from poisonous plants are derived, poisonous plants are one of the most important causes of economic loss to the livestock industry. However, averages are somewhat misleading in that they do not take into account management. An important question is how much could economic losses from poisonous plants be reduced with improved grazing management? This issue will be explored.

\section{Grazing Management and Poisonous Plant Availability}

\section{Grazing Intensity}

Poisonous plant abundance on rangelands has been linked with overgrazing from the beginning of scientific range management in the late 1800 's. Smith $(1895,1899)$ in west Texas, Colville (1898) in Oregon, Nelson (1898) in
Wyoming, and Wooton (1915) in New Mexico all commented that overstocking caused a decline in palatable forage plants and an increase in unpalatable poisonous plants. Through the years various papers have described how and why retrogression from palatable to unpalatable plant species occurs under heavy or severe grazing pressure (Ellison 1960, Cronin et al. 1978, Laycock 1978, Molyneuax and Ralphs 1992). The processes were summarized by Holechek et al. (2001) as follows:

"Under moderate or light grazing levels the poisonous, unpalatable plants are at a competitive disadvantage because they invest part of their products from photosynthesis in poisonous compounds (alkaloids, oxalates, glycosides, etc.) and appendages (spines, thorns, stickers, etc.) that discourage defoliation rather than contribute to growth...In contrast the palatable plants use their photosynthetic products mainly for growth in the form of roots, leaves, stems, rhizomes, stolons, seeds, and so forth. Under heavy defoliation levels the photosynthetic capacity of the palatable plants is reduced to the point that they are unable to produce enough carbon compounds for maintaining root systems, regeneration of leaves, respiration and reproduction. Over time, they shrink and die, and gradually are replaced with the unpalatable plants that are able to defend themselves against defoliation."

Various long-term grazing studies in North America support the above statement (Table 1). The concept advanced by Dyksterhuis (1949) that the more palatable species increase and least palatable species decrease under light to moderate grazing pressure is well supported by the literature (Table 1). On the other hand, the literature consistently shows species that are unpalatable or low in palatability tend to increase under heavy grazing pressure. The only major exception was the California annual grassland type where vegetation compositional changes were not greatly affected by grazing pressure.

Another minor exception was the study by Burzlaff and Harris (1969) in the shortgrass prairie of Nebraska. However, Vallentine (1990) noted that this study was conducted under favorable precipitation conditions. After the study was reported, 2 years of severe drought occurred that reduced the tallgrasses and midgrasses under all grazing intensities. However, the deleterious effects of the drought on the forage stand, including wind erosion, were much more severe under the heaviest stocking rate. 
Table 1. Summary of studies evaluating influence of grazing intensities and grazing systems on long-term trend in palatable, unpalatable, and poisonous plant levels on North American rangelands.

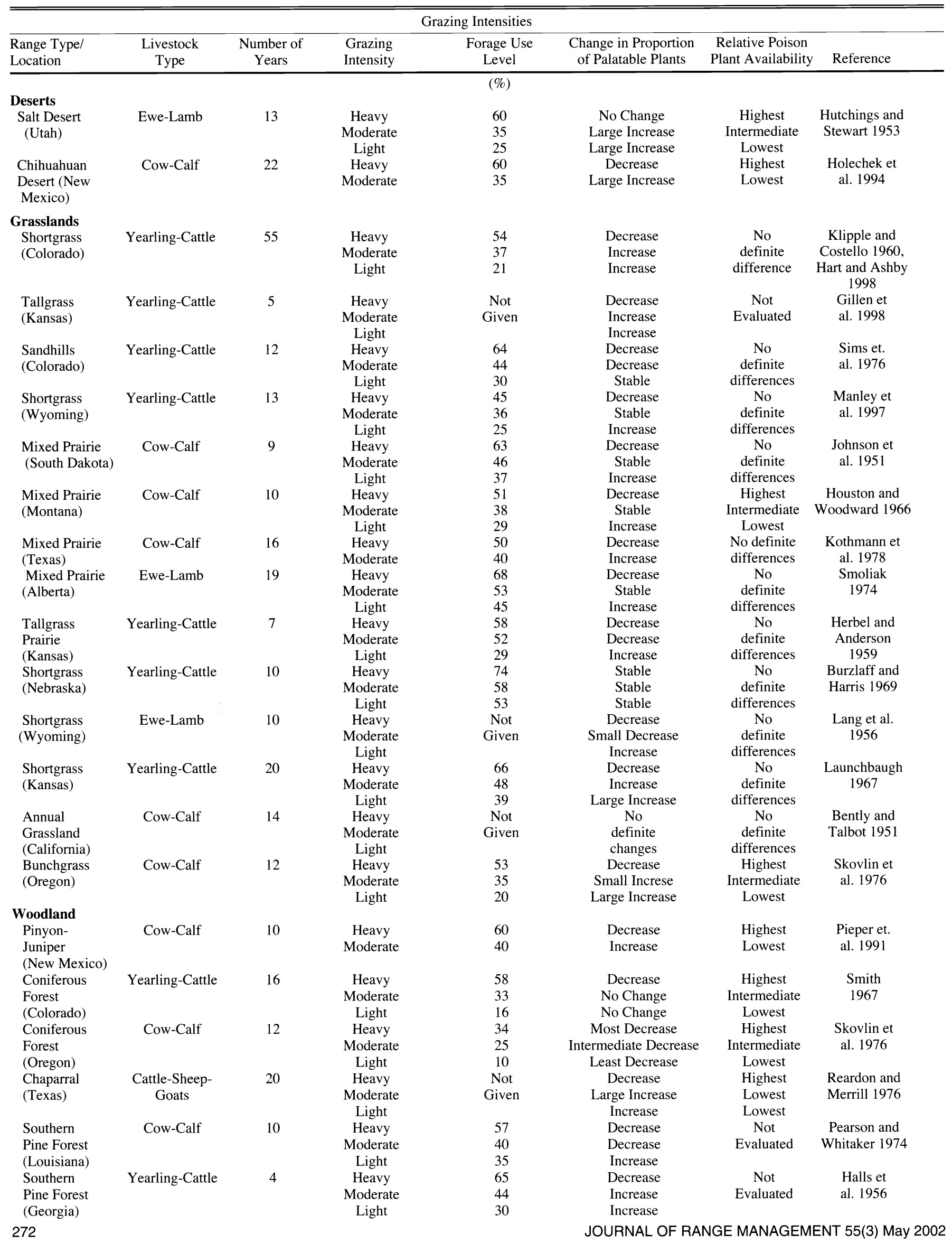


Table 1. Continued.

\begin{tabular}{|c|c|c|c|c|c|c|c|}
\hline \multicolumn{8}{|c|}{ Grazing Systems } \\
\hline $\begin{array}{l}\text { Range Type/ } \\
\text { Location }\end{array}$ & $\begin{array}{l}\text { Livestock } \\
\text { Type }\end{array}$ & $\begin{array}{l}\text { Number of } \\
\text { Years }\end{array}$ & $\begin{array}{l}\text { Grazing } \\
\text { Systems }\end{array}$ & $\begin{array}{l}\text { Forage Use } \\
\text { Level }\end{array}$ & $\begin{array}{l}\text { Change in Proportion } \\
\text { of Palatable Plants }\end{array}$ & $\begin{array}{l}\text { Relative Poison } \\
\text { Plant Availability }\end{array}$ & Reference \\
\hline \multicolumn{8}{|c|}{$(\%)$} \\
\hline $\begin{array}{l}\text { Deserts } \\
\text { Sonoran Desert } \\
\text { (Arizona) }\end{array}$ & Cow-Calf & 10 & $\begin{array}{l}\text { Yearlong } \\
\text { Rotation }\end{array}$ & $\begin{array}{l}52 \\
48\end{array}$ & $\begin{array}{l}\text { No Change } \\
\text { No Change }\end{array}$ & $\begin{array}{c}\text { No } \\
\text { Difference }\end{array}$ & $\begin{array}{c}\text { Martin and } \\
\text { Severson } 1988\end{array}$ \\
\hline \multicolumn{8}{|l|}{ Grasslands } \\
\hline $\begin{array}{l}\text { Mid-grass Prairie } \\
\text { (Texas) }\end{array}$ & Cow-Calf & 16 & $\begin{array}{l}\text { Yearlong } \\
\text { Rotation }\end{array}$ & $\begin{array}{l}35 \\
35\end{array}$ & $\begin{array}{l}\text { Increase } \\
\text { Increase }\end{array}$ & $\begin{array}{c}\text { No } \\
\text { Difference }\end{array}$ & $\begin{array}{l}\text { Kothmann et } \\
\text { al. } 1978\end{array}$ \\
\hline $\begin{array}{l}\text { Tall-grass Prairie } \\
\text { (Kansas) }\end{array}$ & Yearling-Cattle & 16 & $\begin{array}{l}\text { Season-Long } \\
\text { Rotation }\end{array}$ & $\begin{array}{l}52 \\
45\end{array}$ & $\begin{array}{l}\text { Most Decrease } \\
\text { Least Decrease }\end{array}$ & $\begin{array}{l}\text { No Definite } \\
\text { Difference }\end{array}$ & $\begin{array}{l}\text { Owensby et } \\
\text { al. } 1973\end{array}$ \\
\hline $\begin{array}{l}\text { Tall-grass Prairie } \\
\text { (Texas) }\end{array}$ & Cow-Calf & 6 & $\begin{array}{l}\text { Yearlong } \\
\text { Rotation }\end{array}$ & $\begin{array}{l}43 \\
41\end{array}$ & $\begin{array}{l}\text { No Change } \\
\text { No Change }\end{array}$ & $\begin{array}{c}\text { No } \\
\text { Difference }\end{array}$ & Drawe 1988 \\
\hline $\begin{array}{l}\text { Shortgrass Prairie } \\
\text { (Wyoming) }\end{array}$ & Yearling-Cattle & 13 & $\begin{array}{l}\text { Season-Long } \\
\text { Rotation }\end{array}$ & $\begin{array}{l}40 \\
40\end{array}$ & $\begin{array}{l}\text { No Definite Change } \\
\text { Decrease }\end{array}$ & $\begin{array}{l}\text { Lowest } \\
\text { Highest }\end{array}$ & $\begin{array}{l}\text { Manley et. } \\
\text { al. } 1997\end{array}$ \\
\hline $\begin{array}{l}\text { Tall-grass Prairie } \\
\text { (Oklahoma) }\end{array}$ & Yearling-Cattle & 5 & $\begin{array}{l}\text { Season-Long } \\
\text { Rotation }\end{array}$ & $\begin{array}{l}\text { Not } \\
\text { Given }\end{array}$ & $\begin{array}{l}\text { No Change } \\
\text { No Change }\end{array}$ & $\begin{array}{c}\text { No } \\
\text { Difference }\end{array}$ & $\begin{array}{l}\text { Gillen et } \\
\text { al. } 1998\end{array}$ \\
\hline $\begin{array}{l}\text { Mid-grass Prairie } \\
\text { (Alberta, Canada) }\end{array}$ & Yearling-Cattle & 9 & $\begin{array}{l}\text { Season-Long } \\
\text { Rotation }\end{array}$ & $\begin{array}{l}44 \\
46\end{array}$ & $\begin{array}{l}\text { Increase } \\
\text { Increase }\end{array}$ & $\begin{array}{c}\text { No } \\
\text { Difference }\end{array}$ & Smoliak 1960 \\
\hline $\begin{array}{l}\text { Bunchgrass } \\
\text { (Oregon) }\end{array}$ & Cow-Calf & 10 & $\begin{array}{l}\text { Season-Long } \\
\text { Rotation }\end{array}$ & $\begin{array}{l}30 \\
27\end{array}$ & $\begin{array}{l}\text { Most Increase } \\
\text { Least Increase }\end{array}$ & $\begin{array}{c}\text { No } \\
\text { Difference }\end{array}$ & $\begin{array}{l}\text { Skovlin et } \\
\text { al. } 1976\end{array}$ \\
\hline \multicolumn{8}{|l|}{ Woodland } \\
\hline $\begin{array}{l}\text { Chaparral } \\
\text { (Texas) }\end{array}$ & $\begin{array}{l}\text { Cattle-Sheep- } \\
\text { Goats }\end{array}$ & 20 & $\begin{array}{l}\text { Yearlong } \\
\text { Rotation }\end{array}$ & $\begin{array}{l}\text { Not } \\
\text { Given }\end{array}$ & $\begin{array}{l}\text { Least Increase } \\
\text { Most Increase }\end{array}$ & $\begin{array}{l}\text { Highest } \\
\text { Lowest }\end{array}$ & $\begin{array}{l}\text { Reardon and } \\
\text { Merrill } 1976\end{array}$ \\
\hline $\begin{array}{l}\text { Pinyon-Juniper } \\
\text { (New Mexico) }\end{array}$ & Cow-Calf & 10 & $\begin{array}{l}\text { Yearlong } \\
\text { Rotation }\end{array}$ & $\begin{array}{l}40 \\
55\end{array}$ & $\begin{array}{l}\text { No Definite Change } \\
\text { No Definite Change }\end{array}$ & $\begin{array}{l}\text { No Definite } \\
\text { Difference }\end{array}$ & $\begin{array}{l}\text { Pieper et } \\
\text { al. } 1991\end{array}$ \\
\hline $\begin{array}{l}\text { Coniferous Forest } \\
\text { (Oregon) }\end{array}$ & Cow-Calf & 12 & $\begin{array}{l}\text { Season-Long } \\
\text { Rotation }\end{array}$ & $\begin{array}{l}21 \\
23\end{array}$ & $\begin{array}{l}\text { Most Decrease } \\
\text { Least decrease }\end{array}$ & $\begin{array}{c}\text { No } \\
\text { Difference }\end{array}$ & $\begin{array}{l}\text { Skovlin et } \\
\text { al. } 1976\end{array}$ \\
\hline
\end{tabular}

Evidence that heavy grazing increases poisonous plant availability is more limited than that for plants of low palatability. However, 7 of the 22 grazing studies reviewed in Table 1 showed poisonous plants were definitely more available under heavy grazing on a biomass basis than under moderate to light grazing. These studies supported the theory that heavy grazing causes vegetational composition shifts towards poisonous plants. Desert and woodland studies showed more tendency for poisonous plants to increase under heavy grazing than those from grasslands.

Two important reasons why 12 of the 22 studies reviewed showed no definite increase in poisonous plants under heavy grazing may have to do with the relatively short time frame of the studies and lack of severity in the heavy grazing treatment. Fusco et al. (1995), on Chihuahuan Desert grassland rangeland in New Mexico, found that poisonous plants totally dominated areas within 1,000 meters of permanent waters on rangelands with a 50 year history of heavy grazing. However, on rangelands with a 50 year history of conservative grazing, the zone of poisonous plant domination extended only 500 meters from water. Across the entire study areas, poisonous plant biomass levels were $57 \%$ higher on the long term heavy compared to conservative grazed range.

\section{Grazing Systems}

Generally, rotation and year-long or season-long grazing systems have shown little difference in their effects on proportions of decreaser and poisonous plants (Table 1). An exception is chaparral range type of south Texas where the Merrill 3-herd/4pasture system has definitely favored decreaser plants and reduced poisonous plants (Reardon and Merrill 1976, Merrill and Schuster 1978, Taylor and Ralphs 1992). A modification of the Merrill 3herd/4-pasture system may have reduced white loco (Oxytropis sericea Nutt.) availability on mountain range in Utah (Taylor and Ralphs 1992). The literature convincingly shows grazing intensity has far more impact on vegetation composition changes through time than system of grazing.

\section{Poison Plant Availability and Livestock Food Habits}

Research is restricted on how range condition and grazing management affect poisonous plant levels in livestock diets. One study from the Chihuahuan Desert of south-central New Mexico evaluated poisonous plant levels in cattle diets over a 3 year period on rangelands in late-seral and mid-seral ecological condition (Daniel et al. 1993). Both areas were stocked conservatively, but poisonous plant biomass lev- els were about $60 \%$ higher on the midseral compared to late-seral range. Across the 3 year study period poisonous plants comprised $14 \%$ and $10 \%$ of cattle diets by weight and late- and mid-seral ranges, respectively. Total poisonous plant consumption never exceeded $20 \%$ of the diet on either range. Over a 3 year period no death losses from poisonous plants $(220$ cattle/year) were observed on either range (Fusco et al. 1995). Results from this study indicated that poisonous plant consumption by livestock is more related to grazing intensity than rangeland condition.

\section{Grazing Management and Livestock Losses to Poisonous Plants}

\section{Grazing Intensity}

Several range researchers and managers through the years have noted that elevated livestock death losses from poisonous plants were associated with heavy grazing intensities (Smith 1899, Stoddart and Smith 1943, Shoop and McIlvain 1971, Merrill and Schuster 1978, Taylor and Ralphs 1992). Various grazing studies generally supported by actual research show this observation (Table 2). Based on the author's review, sheep and goat death 
losses from poisonous plants are more elevated by heavy grazing than those from cattle. Generally, grazing intensities must involve more than $50 \%$ use of palatable forage species for elevated poisonous plant losses to occur. The author has had opportunity to evaluate cattle death losses from poisonous plants on several rangelands in Oregon and New Mexico. On mountain rangeland (the Starkey Experimental Range) in northeastern Oregon 100 yearling cattle per year over a 3 year period for a 120 day grazing season ( 20 June to 20 October) have been observed by the author. These rangelands were generally in high ecological condition and conservatively stocked. Only 2 animals died from poisonous plants over the 3 year period (Holechek 1980).

In south-central New Mexico, over the past 11 years, cattle death losses on the Chihuahuan Desert Rangeland Research Center and several surrounding rangelands under the control of the Bureau of Land Management have been monitored by the author. On the Chihuahuan Desert Rangeland Research Center, death losses to poisonous plants have been no more than $1 \%$ per year $(1,100$ observations). This area is generally in high ecological condition and pastures are conservatively or moderately stocked. On surrounding rangelands in lower ecological condition low death losses $(1-2 \%)$ have been observed when grazing intensities were conservative to moderate (Fusco et al. 1995). However, when grazing intensities reached heavy to severe levels (over $60 \%$ use of forage) death losses in the spring were elevated to $4-8 \%$.

On 2 occasions the author investigated cases where cattle death losses from poisonous plants took 10 to $25 \%$ of the herd. In these situations, grazing intensity was so severe (over $70 \%$ use of forage) that livestock had little choice other than to consume unpalatable/poisonous plants or starve. Based on these experiences, along with a review of the literature, the author concludes that heavy to severe livestock grazing pressure is generally the cause of excessive death losses to poisonous plants.

Holechek et al. $(1999,2001)$ review several long term grazing studies that show calf and lamb crops are closely associated with grazing intensity. Calf crops under heavy, moderate, and light grazing averaged $72 \%$, $79 \%$, and $82 \%$, respectively, across all studies (Holechek et al. 1999). Lamb crops averaged $78 \%, 82 \%$, and $87 \%$ across heavy, moderate, and light grazing intensities. Part of the depressed calf and lamb crops under the heavily grazed treatment in several of these studies was probably due to poisonous plant consumption. However, separation of poisonous plant from nutritional influences has not been done.

\section{Grazing Systems}

Livestock death losses under continuous and rotation grazing systems have shown little to no difference with 1 exception (Table 2). On chaparral rangeland in southcentral Texas the Merrill 3-herd/4-pasture system has reduced livestock (cattle-sheepgoats) death losses compared to continuous grazing (Merrill and Schuster 1978, Taylor and Ralphs 1992). Lower poisonous plant availability (Table 1) appears to explain why livestock death losses have been

Table 2. Summary of studies evaluating influence of grazing intensities and grazing systems on livestock death losses from poisonous plants.

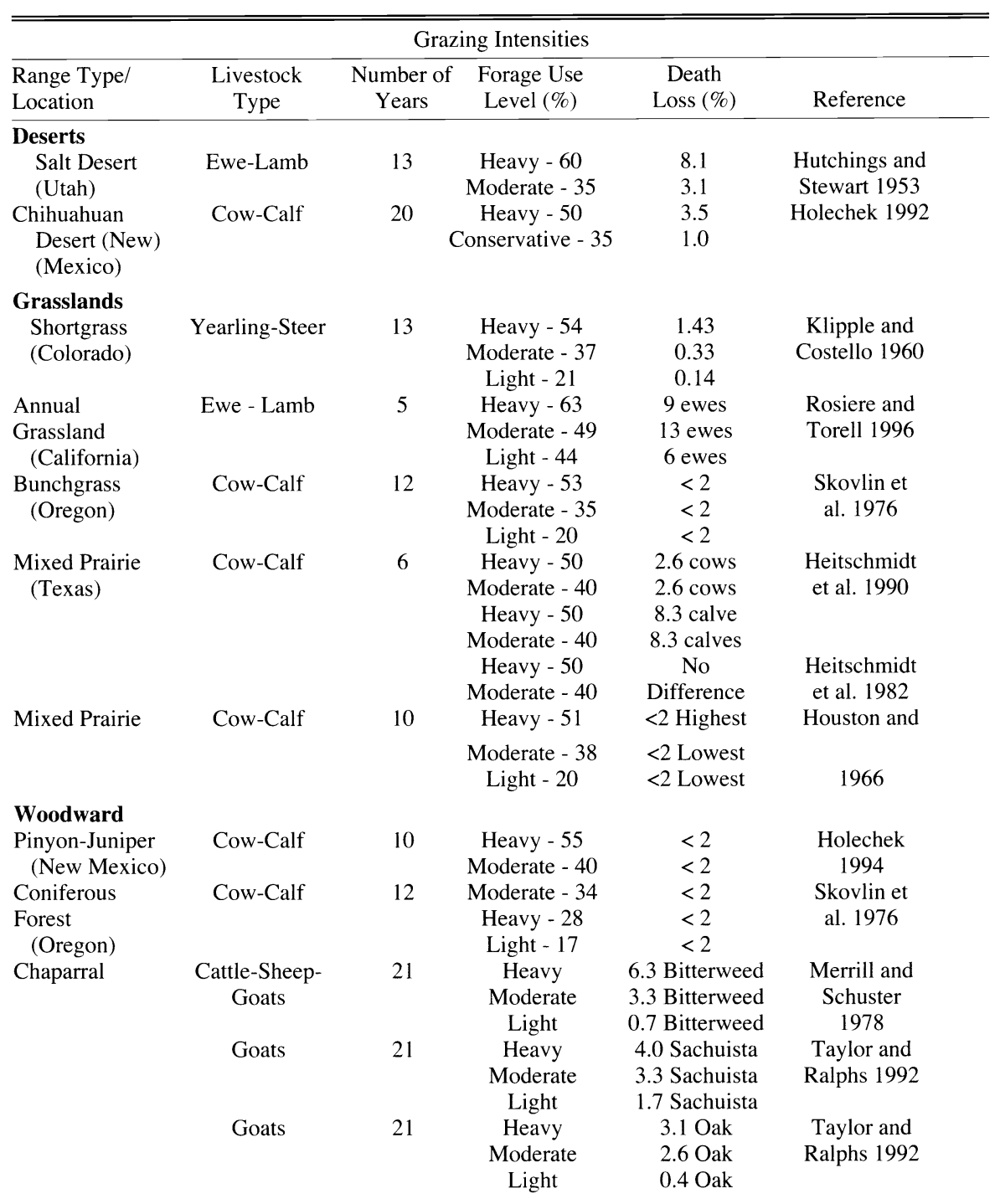

Table 2 continued on page 275 almost nil under the Merrill system (Reardon and Merrill 1976).

Application of the Merrill 3-herd/4-pasture system on mountain range in Utah reduced the number of sick calves from poisoning by white locoweed (Oxytropis sericea Nutt) from 20 to $3 \%$ compared to rest-rest rotation grazing (Taylor and Ralphs 1992). Under rest-rotation grazing, the entire herd was concentrated into 1 pasture to force even use of all forage, including locoweed. In the Merrill 3herd/4-pasture system, the grazing pressure was distributed over 3 pastures, and cattle were not forced to eat locoweed. A shortened grazing season also contributed to reduction in losses by removing all the animals before intoxication became serious or irreversible. 
Table 2. Continued.

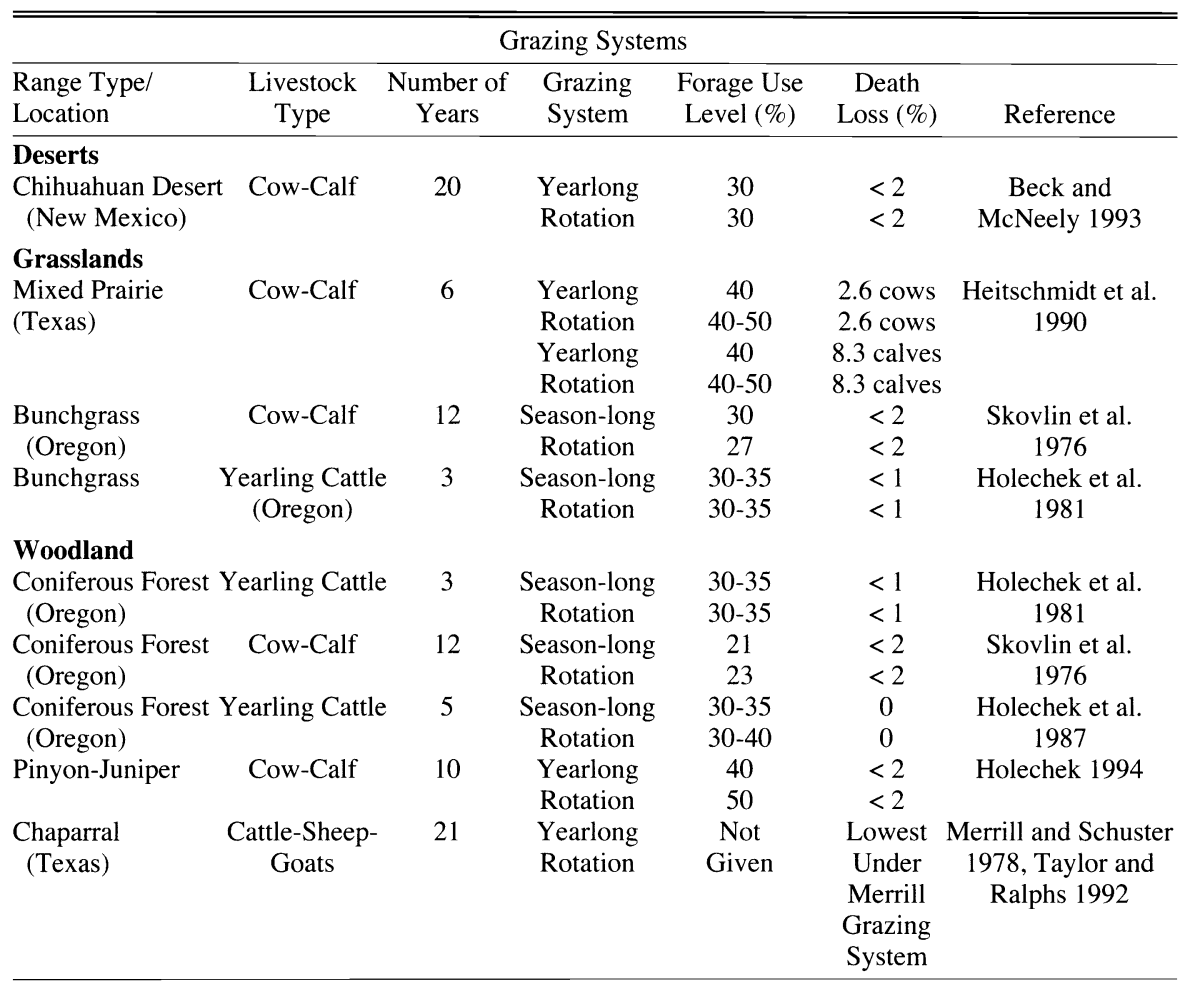

\section{Multi-Species Grazing}

Multi-species grazing involving cattlesheep and goats has reduced livestock death losses from poisonous plants on chaparral ranges in south-central Texas (Merrill and Schuster 1978, Taylor and Ralphs 1992). Sheep death losses to bitterweed (Hymenoxys odorata D.C.) were greatest on pastures stocked with sheep only and least with a combination of multi-species grazing (cattle-sheep-goats), moderate stocking, and Merrill 3-herd/4pasture grazing. Goat losses to sacahuista (Nolina texana wats.) were reduced by multi-species grazing. However, goat losses due to oak (Quercus spp.) consumption were little affected by stocking rate, multispecies grazing, or grazing system. Taylor and Ralphs (1992) concluded that grazing management alone will not eliminate livestock death losses caused by consumption of poisonous plants. However, livestock losses can be reduced through proper grazing management.

\section{Special Poisonous Plant Problems}

Certain poisonous plants have caused inordinate problems to livestock producers because of their widespread distribution and/or palatability to livestock under cer- tain conditions. Considerable research has been directed towards management of livestock and rangelands to minimize losses from these plants. A more detailed discussion is presented by other papers in this symposium. Readers are also referred to Kingbury (1964), James and Johnson (1976), Keeler et al. (1978), James et al. (1988), Taylor and Ralphs (1992), and James et al. (1992) for overviews of specific management strategies to deal with various poisonous plants.

\section{Summary and Conclusions}

In this review of livestock poisonous plant losses and grazing management, 3 issues were addressed in some detail. These include the influence of grazing management on poisonous plant availability, poisonous plant consumption, and livestock death losses from poisonous plants. Long term studies were quite consistent in showing heavy grazing intensities increased proportions of unpalatable plants on most rangelands. This same relationship also occurred for poisonous plants but fewer studies confirmed it. Generally, poisonous plant levels on rangelands showed few differences among continuous and rotation grazing systems. However, there was evidence the Merrill 3 herd/4 pasture system in South Texas lowered poisonous plant levels compared to continuous grazing. Research regarding poisonous plant levels in livestock diets under different ecological condition levels and grazing management strategies is somewhat restricted. Available studies indicate poisonous plant consumption is much more related to grazing intensity than rangeland ecological condition. Actual death losses from poisonous plants were strongly related to grazing intensity and, to a much lesser extent, grazing system. The Merrill 3 herd/4 pasture system has lowered cattle, sheep, and goat death losses from poisonous plants in south Texas compared to continuous grazing. Carefully timed grazing can be used to minimize cattle losses from larkspur and locoweed. Aversive conditioning and herbicidal control of dense stands can be effective in reducing livestock losses to these plants. Proper stocking and careful timing of grazing are critical management practices in minimizing livestock losses from poisonous plants. In conclusion most livestock losses from poisonous plants do result from "poor" range management.

\section{Literature Cited}

Beck, R. F. and R. P. McNeely. 1993. Twentyfive year summary of year-long and seasonal grazing on the College Ranch. Livestock Research Briefs and Cattle Growers Short Course. New Mexico State University, Las Cruces, N.M.

Bentley, J. R. and M. W. Talbot. 1951. Efficient use of annual plants on cattle ranges in the California foothills. U.S. Dept. Agr.. Circ. 870.

Burzlaff, D. F. and L. Harris. 1969. Yearling steer gains and vegetation changes of western Nebraska rangeland under three rates of stocking. Nebr. Agr. Exp. Sta. Bull. 505.

Colville, F. J. 1898. Forest growth and sheep grazing in the Cascade Mountains of Oregon. U.S. Dept. Agr. For. Div. Bull. 15.

Cronin, E. H., P. Ogden, J. A. Young, and W. Laycock. 1978. The ecological niches of poisonous plants in range communities. J. Range Manage. 31:328-334.

Daniel, A., J. L. Holechek, R. Valdez, A. Tembo, L. Saiwana, M. Fusco, and $M$. Cardenas. 1993. Range condition influences on Chihuahuan Desert cattle and jackrabbit diets. J. Range Manage. 46:296-301.

Drawe, D. L. 1988. Effects of three grazing treatments on vegetation, cattle production, and wildlife on the Welder Wildlife Foundation Refuge, 1974-1982. Welder Wildl. Found. Contrib. B-8, Sinton, Tex.

Dyksterhuis, E.J. 1949. Condition and Management of Rangeland based on quantitative ecology. J. Range Manage. 2:104-115.

Ellison, L. 1960. Influence of grazing on plant succession of rangeland. Bot. Rev. 26:1-78. 
Fusco, M., J. Holechek, A. Tembo, H. Daniel, and M. Cardenas. 1995. Grazing influences on watering point vegetation in the Chihuahuan Desert. J. Range Manage. 48:32-38.

Gay, C. W. and D. D. Dwyer. 1967. Poisonous range plants. New Mexico State Univ. Coop. Ext. Serv. Circ. 391

Gillen, R. L., F. T. McCollum III, K. W. Tate, and M. E. Hodges. 1998. Tallgrass prairie response to grazing system and stocking rate. J. Range Manage. 51:139-146.

Hart, R. H. and M. M. Ashby. 1998. Grazing intensities, vegetation, and heifer gains: 55 years on shortgrass. J. Range Manage. 51:392-398.

Halls, L. K., O. M. Hale, and B. L. Southwell. 1956. Grazing capacity of wiregrass-pine ranges of Georgia. Georgia Agr. Exp. Sta. Tech. Bull. N.S. 2 .

Heady, H. F and R. D. Child. 1994. Rangeland ecology and management. Westview Press, San Francisco, Calif.

Heitschmidt, R. K., M. M. Kothmann, and W. J. Rawlins. 1982. Cow-calf response to stocking rates, grazing systems, and winter supplementation at the Texas Experimental Ranch. J. Range Manage. 35:204-210.

Heitschmidt, R. K., J. R. Conner, S. K. Canon, W. E. Pinchak, J. W. Walker, and S. L. Dowhower.1990. Cow/calf production and economic returns from yearlong continuous deferred rotation and rotational grazing treatments. J. Agr. Prod. 3:92-99.

Herbel, C. H. and K. L. Anderson. 1959. Response of true prairie vegetation on major Flint Hills range sites to grazing treatment. Ecol. Monogr. 29:171-198.

Holechek, J. L. 1980. The effects of vegetation type and grazing system on the performance, diet, and intake of yearling cattle. Ph.D. Thesis. Oregon State Univ., Corvallis, Ore.

Holechek, J. L. 1992. Financial aspects of cattle production in the Chihuahuan Desert. Rangelands 14:145-149.

Holechek, J. L. 1994. Financial returns from different grazing management systems in New Mexico. Rangelands 16:237-240.

Holechek, J. L, T. J. Berry, and M. Vavra. 1987. Grazing system influences on cattle diet and performance on mountain range. J. Range Manage. 40:55-60.

Holechek, J. L., C. H. Herbel, and R. D. Pieper. 2001. Range management: principles and practices. $4^{\text {th }}$ Ed. Upper Saddle River, N.J.

Holechek, J. L., M. Vavra, and J. Skovlin. 1981. Diet quality and performance of cattle on forest and grassland range. J. Anim. Sci. 53:291-299.

Holechek, J. L., H. Gomez, F. Molinar, and D. Galt. 1999. Grazing studies: What we've learned. Rangelands 21(2):12-16.

Holechek, J. L., A. Tembo, A. Daniel, M. Fusco, and M. Cardenas. 1994. Long term grazing influences on Chihuahuan Desert rangeland. Southw. Nat. 39:342-349.

Houston, W. R. and R. R. Woodward. 1966. Effects of stocking rates on range vegetation and beef cattle production in the northern Great Plains. U. S. Dept. Agr. Tech. Bull. 1357.

Hutchings, S.S. and G. Stewart. 1953. Increasing forage yields and sheep production on intermountain winter ranges. U.S. Dept. Agr. Cic. 925
James, L. F. 1978. Overview of poisonous plan problems in the United States. p. 3-5. In Richard F. Keeler, Kent R. Van Kampen, and Lynn F. James (ed.) Effects of poisonous plants on livestock.

James, L. F. and A. E. Johnson. 1976. Some major plant toxicities in the western United States. J. Range Manage. 29:356-363.

James. L. F., M. H. Ralphs, and D. B. Nielsen (eds.). 1988. The ecology and economic impact of poisonous plants on livestock production. Westview press, Boulder, Colo.

James, L. F., D. B. Nielsen, and K. E. Panter. 1992. Impact of poisonous plants on the livestock industry. J. Range Manage. 45:3-8.

Johnson, L. A., L. A. Albee, R. O. Smith, and A. Moxon. 1951. Cows, calves, and grass. South Dakota Agr. Exp. Sta. Bull. 412.

Keeler, R. F., K. R. Van Kampen, and L. F. James (Eds.). 1978. Effects of poisonous plants on livestock. Academic Press, Inc., New York.

Kingsbury, J. 1964. Poisonous plants of the United States and Canada. Prentice-Hall, Englewood Cliffs, N.J.

Klipple, G. E. and D. F. Costello. 1960. Vegetation and cattle responses to different intensities of grazing on shortgrass ranges of the central Great Plains. U.S. Dept. Agr. Tech. Bull. 1216.

Kothmanm, M. M., J. Waldrip, and G. W. Mathis. 1978. Rangeland vegetation of the Texas Rolling Plains: response to grazing management and weather. Proc. Internat. Rangeland. Congr. 1:607-610.

Lang, R. L., O. K. Barnes, and F. Rauzi. 1956. Shortgrass range-grazing effects on vegetation and on sheep gains. Wyoming Agr. Exp. Sta. Bull. 343.

Launchbaugh, J. L. 1967. Vegetation relationships associated with intensity of summer grazing on a clay upland range site in the Kansas 20-24 inch precipitation zone. Kansas Agr. Exp. Sta. Tech. Bull. 154

Laycock, W. A. 1978. Coevolution of poisonous plants and large herbivores on rangelands. J. Range Manage. 31:335-343.

Lang, R. L., O. K. Barnes, and F. Rauzi. 1956. Shortgrass range-grazing effects on vegetation and on sheep gains. Wyoming Agr. Exp. Sta. Bull. 343 .

Manley, W. A., R. H. Hart, M. A. Smith, J. W. Waggoner Jr., and J. T. Manley. 1997. Vegetation, cattle, and economic responses to grazing strategies and pressure. J. Range Manage. 50:638-646.

Martin, S. C. and K. E. Severson. 1988. Vegetation response to the Santa Rita grazing system. J. Range Manage. 41:291-296.

Merrill, L. B. and J. L. Schuster. 1978. Grazing management practices affect livestock losses from poisonous plants. J. Range Manage. 31:351-354

Molyneaux, R. J. and M. Ralphs. 1992. Plant toxins and palatability to herbivores. J. Range Manage. 45:13-18.

Nelson, A. 1898. The red desert of Wyoming and its forage resources. U.S. Dep. Agr. Div. Agrost.Bull. 13.

Nielsen, Darwin B. and Lynn F. James. 1991. Poisonous plants - Proc. $3^{\text {rd }}$ Internat. Symp., Iowa State Univ. Press. Ames, Iowa.
Owensby, C. E., E. F. Smith, and K. L. Anderson. 1973. Deferred rotation grazing with steers in the Kansas Flint Hills. J. Range Manage. 26:393-395.

Pearson, H. A. and L. B. Whitaker. 1974. Forage and cattle responses to different grazing intensities on southern pine range. 27:444-446.

Pieper, R. D., E. E. Parker, G. B. Donart, and J. D. Wright. 1991. Cattle and vegetational response to four-pasture and continuous grazing systems. New Mexico Agr. Exp. Sta. Bull. 576.

Reardon, P. O. and L. B. Merrill. 1976. Vegetative response under various grazing management systems in the Edward Plateau of Texas. J. Range Manage. 29:195-198.

Rosiere, R. E. and D. T. Torell. 1996. Performance of sheep grazing California annual range. Sheep and Goat Res. J. 12:49-58.

Shoop, M. C. and E. H. McIlvain. 1971. Why some cattlemen overgraze and some don't . J Range Manage. 24:252-257.

Sims, P. L., B. E. Dahl, and A. H. Denham. 1976. Vegetation and livestock response at three grazing intensities on sandhill rangeland in eastern Colorado. Colorado State Univ. Exp. Sta. Tech. Bull. 130.

Skovlin, J. M, R. W. Harris, G. S. Strickler, and G. A. Garrison. 1976. Effects of cattle grazing methods on ponderosa pine-bunchgrass range in the Pacific northwest. U.S. Dept. Agr. Tech. Bgull. 1531

Smith, D. R. 1967. Effects of cattle grazing on a ponderosa pine-bunchgrass range in Colorado. U.S. Dept. Agr. For. Serv. Tech. Bull. 1371.

Smith, J. G. 1895. Forage conditions of the prairie region. In: U.S. Department of Agriculture Yearbook. U.S. Gov.Printing Office, Washington, DC

Smith, J. G. 1899. Grazing problems in the southwest and how to meet them. U.S. Dept. Agr. Div. Agrost. Bull. 16:1-47.

Smoliak, S. 1960. Effects of deferred-rotation and continuous grazing on yearling steer gains and shortgrass prairie vegetation of southeastern Alberta. J. Range Manage. 13:239-243.

Smoliak, S. 1974. Range vegetation and sheep production at three stocking rates on StipaBouteloua prairie. J. Range Manage. 27:23-26.

Stoddart, L. A. and A. D. Smith. 1943. Range management. McGraw-Hill Book Company, N.Y.

Taylor, C. A. Jr. and M. H. Ralphs. 1992. Reducing livestock losses from poisonous plants through grazing management. J. Range Manage. 45:9-12.

Torell, L. A., J. M. Hawkes, and T. D. Stromei. 1998. Range livestock cost and return estimates from New Mexico, 1999. New Mexico State Univ. Agr. Exp. Sta. Res. Rept. 726.

USDA. 1968. 22 plants poisonous to livestock in the western states. USDA Agr. Info. Bull. 327.

Vallentine, J. F. 1990. Grazing management. Academic Press Inc., New York, N.Y.

Wooton, E. O. 1915. Factors affecting range management in New Mexico. U.S. Dept. Agr. Bull. 211 